\title{
Developing a Spatial Tool for Assessing Coastal Community and Identifying Infrastructure at Risk
}

\author{
Sultana Nasrin Baby', Colin Arrowsmith1, Gang-Jun Liư1, David Mitchell1, Nadhir Al-Ansari2*, \\ Nahala Abbas ${ }^{3}$
}

${ }^{1}$ School of Mathematical and Geospatial Sciences, Royal Melbourne Institute of Technology (RMIT University), Melbourne, Australia

${ }^{2}$ Lulea University of Technology, Lulea, Sweden

${ }^{3}$ School of Engineering \& Technology, Central Queensland University, Melbourne, Australia

Email: snb.sdml@gamil.com, colinarrowsmith01@gmail.com,gang-jun.liu@rmit.edu.au, david.mitchell@rmit.edu.au,

*nadhir.alansari@ltu.se,nahla12041972@gmail.com

How to cite this paper: Baby, S.N., Arrowsmith, C., Liu, G.-J., Mitchell, D., Al-Ansari, N. and Abbas, N. (2021) Developing a Spatial Tool for Assessing Coastal Community and Identifying Infrastructure at Risk. Engineering, 13, 45-55.

https://doi.org/10.4236/eng.2021.131004

Received: December 5, 2020

Accepted: January 11, 2021

Published: January 14, 2021

Copyright (อ 2021 by author(s) and Scientific Research Publishing Inc. This work is licensed under the Creative Commons Attribution International License (CC BY 4.0).

http://creativecommons.org/licenses/by/4.0/

(c) $\underset{\mathrm{By}}{\text { (i) Open Access }}$

\begin{abstract}
A recent trend of sea level shows constant rising. Sea level rise has caused a significant risk to seaside areas. This study examines the potential effect of climate change and rising sea levels on coastal regions and evaluates the susceptibility of coastal areas in Inverloch, Melbourne Australia. A model of Hypothetically Flooded Zones, based on LiDAR data was built, processed and manipulated in ArcGIS. Through applying this model, the effect of rising sea level on the infrastructures such as buildings, dwellings, roads, land use and the population was assessed. Elevation data sets of varying resolution and accuracy have been processed to show the improved quality of LiDAR data contributes to a more precise delineation of flood-prone coastal lands. After the susceptible areas to sea level rise were delineated, the worst-case scenario was calculated (based on the increase in sea level projected for 2100) and it would impacts about $0.86 \%$ of roads, 221 of different building infrastructures. This method can be used in other areas to protect the coasts due to rapid changes caused by climate change.
\end{abstract}

\section{Keywords}

Sea Level Rise, Lidar, Climate Change, Susceptible Area

\section{Introduction}

Globally, mean sea level has increased by $200 \mathrm{~mm}$ since the late 19th century at a 
rate of $2.8 \mathrm{~mm} /$ year [1]. Rising sea levels have accelerated to $3.2 \mathrm{~mm} /$ year over the last three decades [2] at a rate near the upper end of the Intergovernmental Panel on Climate Change projections [3]. Sea levels have increased around the Australian region, consistent with global trends [1] [2]. Rising sea levels have enhanced the frequency and intensity of extreme sea wave events in Australia and overseas [3]. The rate of extreme sea wave events has become three times more frequent in the latter half of the 20th century compared to the former half [1]. Most experts suggest that by 2100 a rise of sea level within the range of 500 $\mathrm{mm}$ to $1000 \mathrm{~mm}$ is highly likely [4].

The increase in the sea level rise (SLR) due to climate change potentially affects many coastal areas and inundates low-lying regions [5]. Many researchers have studied the SLR and its impacts on the coastal areas and their infrastructures such as buildings and road networks. Such studies are exceptional importance to build informed in general, policymaking relating to climate change and the seal level increase [6]. [7] established GIS methods to evaluate and visualize the regional impacts of future floods, based on a $1-6 \mathrm{~m}$ rise in global sea level. GIS was used to assess the impacts of sea level changes on the Nile Delta. Their analyses concerned primarily land loss and the alteration of soil characteristics on the delta. The analyses were focused heavily on the fieldwork which created the actual coastline [8], examined the impacts of Fiji's sea level rise and storm surge, and eventually [6], established an urban-based sea level rise assessment for the Turkish Coastal Region.

In this paper, the effect of the increase in sea level on the Inverloch coastal areas was analysed using GIS and geospatial analysis toolbox [9] [10]. The key objective of the research is to investigate and evaluate the regional impact of climate change and SLR in Inverloch area. To achieve this objective, the framework should include, firstly, examining the use of GIS methodologies in SLR scenarios and checking data, analysis requirements for SLR modelling. Secondly, the creation of a GIS simulation model to study SLR impacts along the coastal zone [11].

\section{Study Area}

Inverloch is a seaside town located in Victoria, Australia. It is located 143 kilometres south east of Melbourne via the South Gippsland Highway on the Bass Highway at the mouth of Anderson Inlet, in the Bass Coast Shire of Gippsland, Victoria, Australia (Figure 1). Originally known for Anderson Inlet's calm waters, it is now also known for finding Australia's first dinosaur fossil and had a population of 5437 at the 2016 census. Inverloch is a popular tourist destination, particularly for swimming, kitesurfing and windsurfing at the calm waters of Anderson Inlet [9]. Surfing and fishing are also common. The town center of Inverloch contains a range of retail, community, commercial, and recreational structures. Near the foreshore reserve, the built form is generally low rise, and the town center creates a sense of place for residents and visitors. Creating 


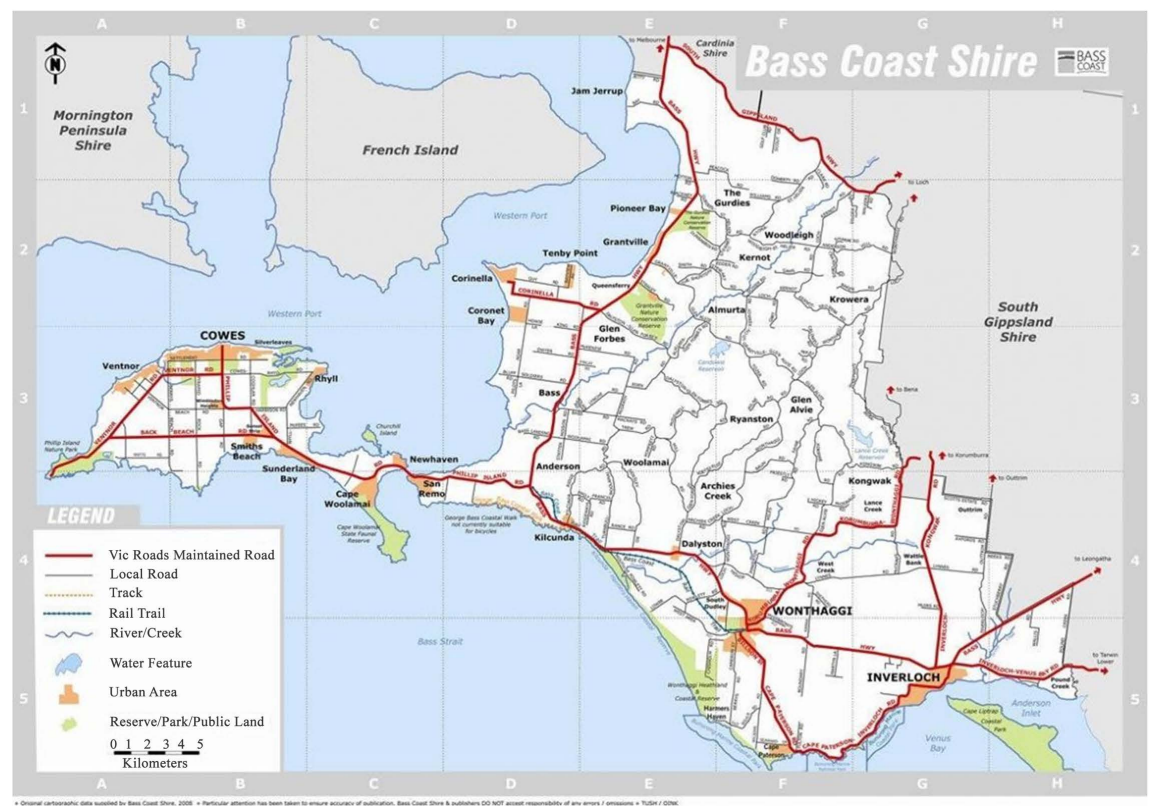

Figure 1. Inverloch sample site in bass coast shire council (Source: BCSC).

pedestrian links and landscaping in the public realm improves the look and enjoyment of the town center. There is also the potential for mixed-use retail with housing above, and creation of infills at the edge of the town centre, with signs of this growth appearing in recent years.

\section{Methods and Data}

The flood models in this research were developed to predict the Inverloch coastal areas that are vulnerable to flooding during a storm if the way the coastal landscape is represented by a DEM will not be altered during the event. The flood models in this research were developed to predict the Inverloch coastal areas that are vulnerable to flooding during a storm if the way the coastal landscape is represented by a DEM will not be altered during the event. Three versions of the flood assessment tool for identifying infrastructure and buildings at risk are available: 1) the first allowing for adding a dam represented by a digitized polyline having a constant level defined by the maximum elevation. The elevation is detected in the DEM underneath the digitized line segments, 2) the second does not include this polyline feature and 3) the third helps to identify infrastructure at risk from SLR flooding. The models are designed for ArcGIS Desktop 10. X with the Spatial Analyst extension [12]. The only data required is a projected DEM, buildings, roads and other assets.

This research aims to demonstrate coastal flood management using a $\mathrm{Li}$ DAR-based DEM to distinguish inland regions that are not hydrologically associated with the sea (Figure 2). Using an accurate elevation model, these inland regions can be identified for exclusion from areas of inundation since they are not hydrologically associated with seawater. This approach to identifying hydrological availability using a LiDAR DEM isn't new [13]. In this study, LiDAR 


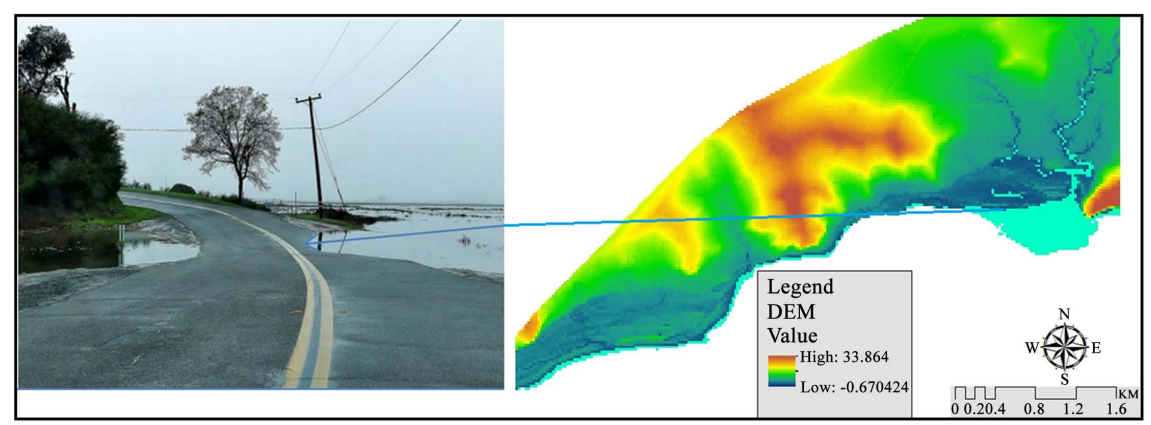

Figure 2. Flood delineation (light blue) representing LiDAR elevation values of less than $1 \mathrm{~m}$ overlaid on a high-resolution LiDAR shaded relief.

data is used for improved hydrological modelling. Coastal inundation mapping, and identification of locations where seawater and inland water meet or connect. This research evaluated each inland region to identify the parts that could be affected by coastal inundation.

\subsection{The iFlood Model}

As illustrated in Figure 3, the main iFlood model requires a point at sea and a dam and the specification of the initial sea level, the sea level incremental values and the number of sea level iterations. Two feature class schemas have been prepared for the digitized point at sea (Ocean Point) and the digitized dam.

This iFlood model illustrated in Figure 3 simulates the impact of flooding caused by temporary water stowage or a constant SLR due to climate change. This version creates a dike by digitization and afterwards, the iFlood model is created. The dike's upper level is set at coastal Z-level (ground) based on the maximum elevation. Also, the ocean floor elevation must be digitized in the flood model.

\subsection{Execution of the iFlood Model without the Digitized Dam}

To simulate an increasing flood caused by temporary sea stowage or a steady SLR due to climate changes, a point located at sea must be digitized to initiate the flood. The flood's initial base level, the incremental SLR and the number of iterations (sea levels modelled) must also be defined, and the resulting rasters are saved in the outputs file geodatabase. The model builder process is illustrated in (Figure 4 and Figure 5).

The three images below show the modelled flood levels and illustrate the impact of the established dam (if present), see Figure 5. Red line is Dam and blue colour water level.

When the model in Figure 6 is completed, it is important to refresh the geodatabase created by ArcGIS (Output.gdb). All modelled sea level outputs are named "Level $\mathrm{xxxCm}$ ", where $\mathrm{xxx}$ is the sea level value in centimetres. The next step is to drag and drop all outputs from the geodatabase into ArcGIS, and then organize the layers so the $250 \mathrm{~cm}$ output is positioned right above the loaded DEM, insert the $250 \mathrm{~cm}$ output on top of that one. The last step is to create the 


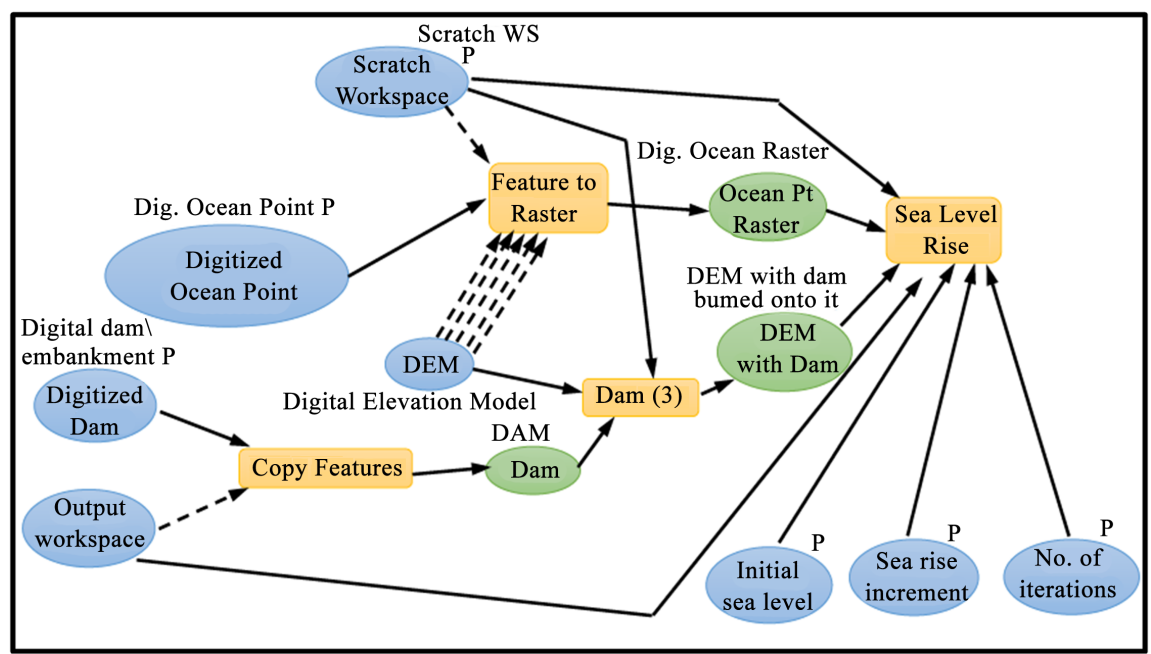

Figure 3. The iFlood model (Adapted from [14]).

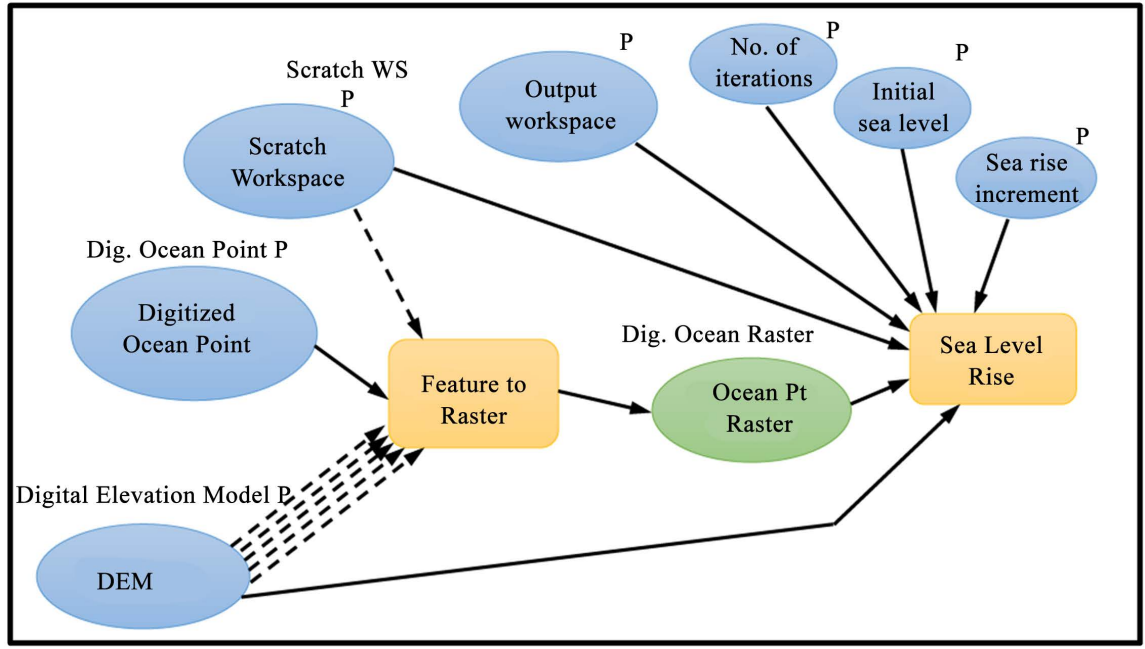

Figure 4. Part of the iFlood model that creates a digitized dam in the initial DEM. The "no dam" version of the iFlood model is executed in the same way as the full iFlood model.

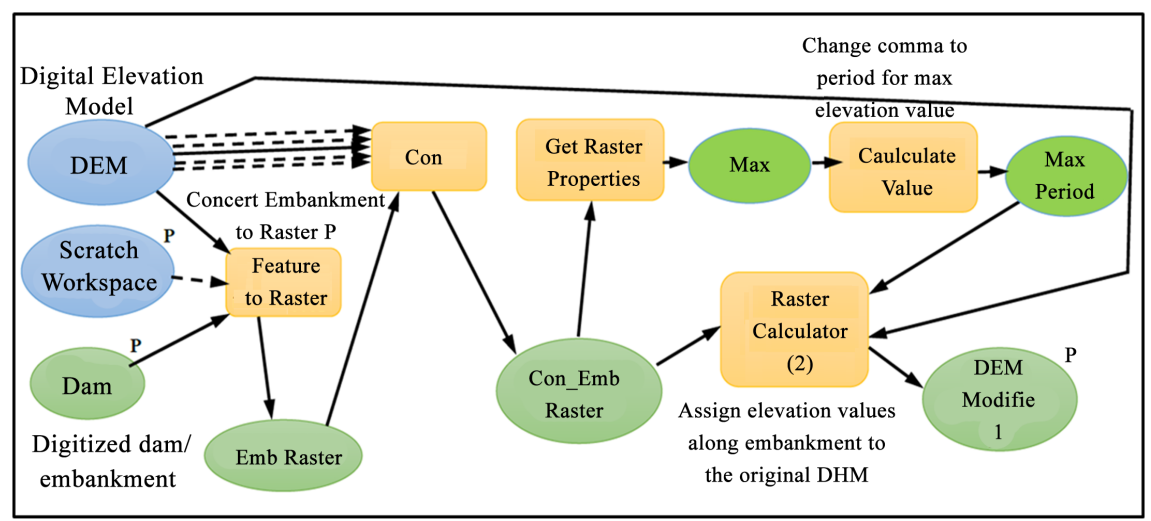

Figure 5. Workflow for digitizing a damwall or embankment as a polyline and burning the polyline onto a DEM. The dam's level is assigned as the maximum. DEM value along the digitized damwall. 

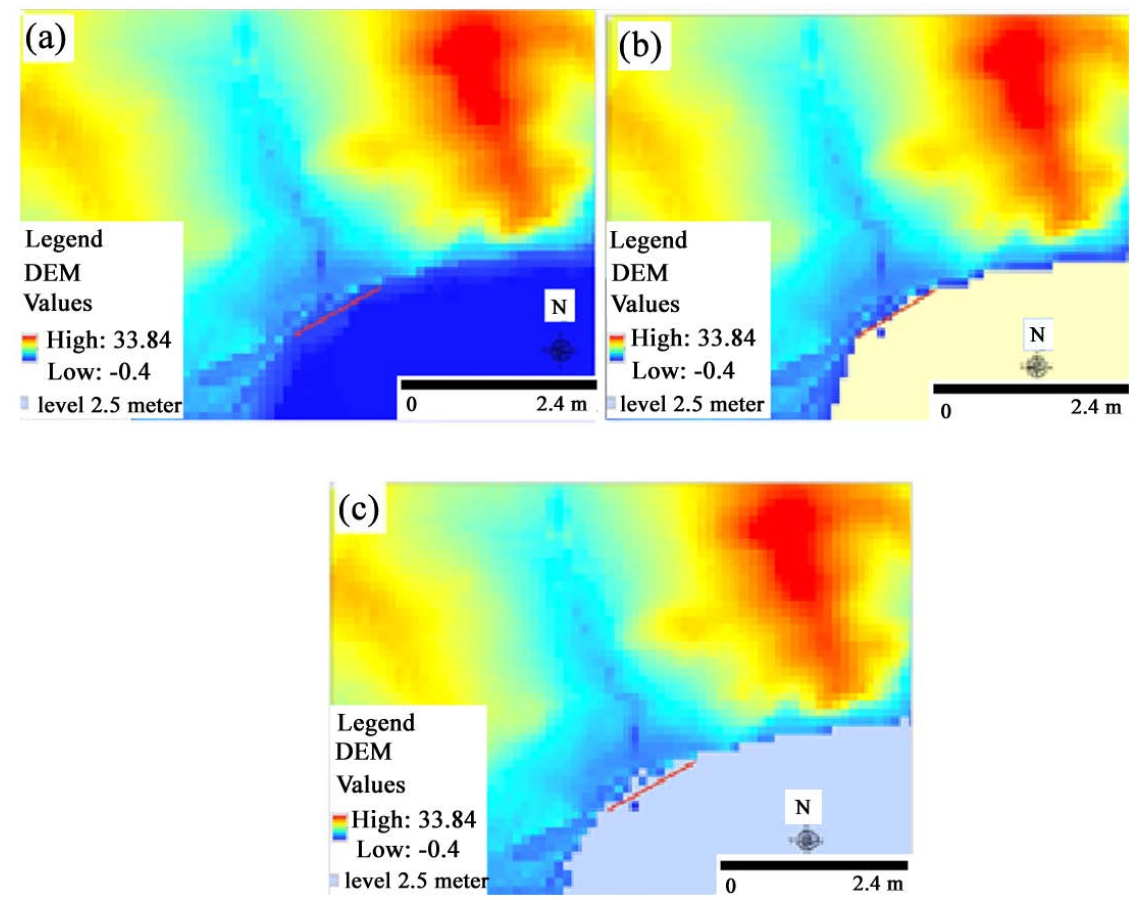

Figure 6. DEM with a $0.9 \mathrm{~m}$ high dam wall added (a), which is flooded with modelled SLR of either $1.0 \mathrm{~m}$ (b) or $2.5 \mathrm{~m}$ (c) above sea level.

digitized dam as the top layer (if present), Figure 6(b) convert 100 centimetres to $1 \mathrm{~m}$.

\subsection{Execution of the Sea Level Rise Flood Mode}

To model coastal areas that would be inundated based on a mean SLR using raster dataset and Map Algebra, flooded cells are identified, classified, grouped, and converted into polygons. The elevation raster is essentially a grid of cells, each cell containing an elevation above mean sea level. If the SLR is 2.5 meters, this must be subtracted from the current elevations that are in the raster assuming that anything below zero is negative. The area of the coast that will be flooded can be estimated by a below water scenario from a non-breaking space (nbsp) [14]. Figure 7 shows a workflow to calculate the areas affected by a rise in sea levels. Ocean point raster must be present before the model is executed.

\section{Results and Discussion}

To calculate the percentage of road length of the town that falls within the flood prone areas, an attribute for the road layer is required. The column called "shape length" only appears in a geodatabase feature class which automatically appends a shape length or shape area, depending on the geometry, to the attribute table so it can then be updated. This provides the real-time data and the units of the coordinate system in metre by using the statistical tool, "r" the total length of streets that fall within the flood area. In the Inverloch area, the total road shape area is 63.70 hectares (ha). Based on the increase in sea level projected for 2100, 


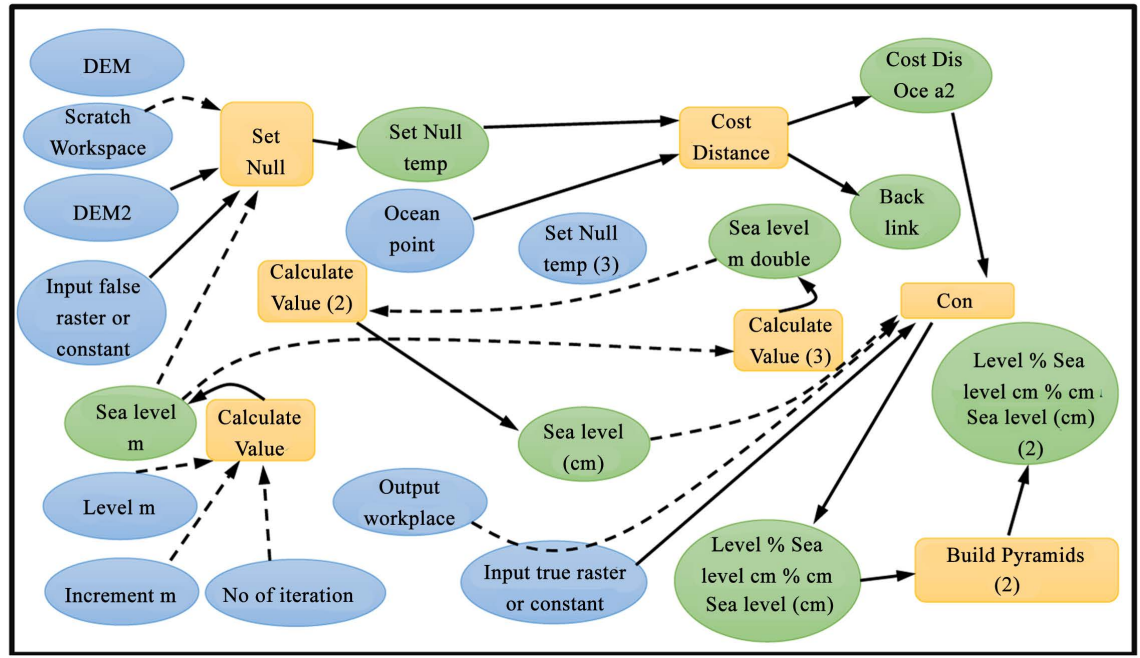

Figure 7. Model to calculate the land area inundated due to SLR.

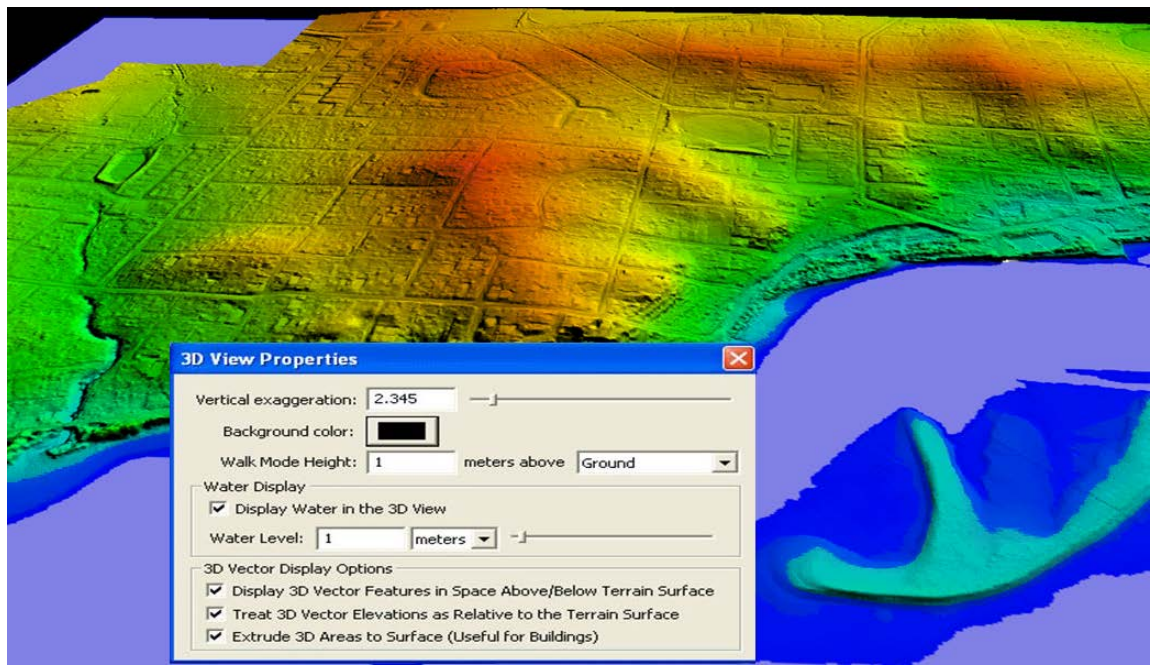

Figure 8. Using LiDAR data to predict sea level rise (blue as watercolour).

the SLR identification of the flood risk to road infrastructure is 1.35 hectares (ha) and $0.86 \%$ of roads. The percentage of the town's roads that fall within flood risk that can be calculated by examining roads lengths within the town looking at the sum for all the roads (approximately 1.35 hectares lengths). The area that was in the flood area was divided by the total area of roads, resulting in $0.9 \%$ of all roads at risk of flooding in the worst-case scenario. Similarly, 6165 buildings were identified as the total number of buildings in the Inverloch area, and of these, for the 2100 SLR scenario 221 building infrastructure was identified as at-risk i.e. 3.6\% buildings will be flooded (Figure 8 and Figure 9).

As illustrated in Figure 10, the Inverloch area land use layer identifies all the different kinds of land use within each neighbourhood. This layer is used throughout Australia and can be complicated, depending on the size and the activity that goes on in a neighbourhood. For the land use description field, six separate colours were applied to each category to distinguish the variety. The 


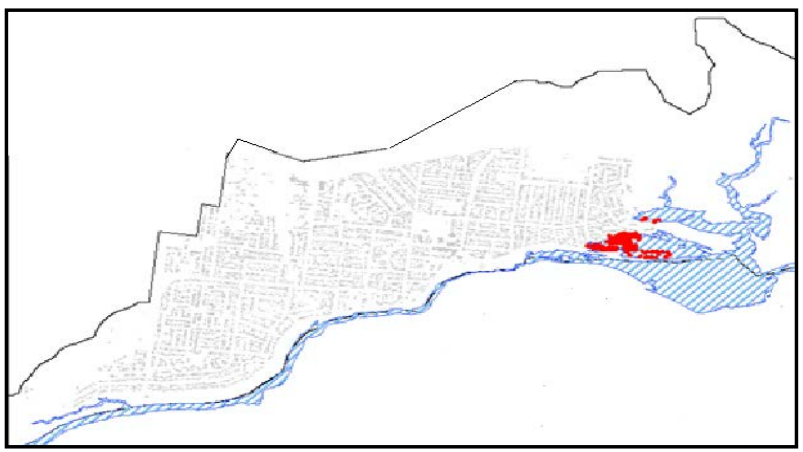

Figure 9. Buildings at risk from $2 \mathrm{~m}$ SLR flooding (highlighted in red).

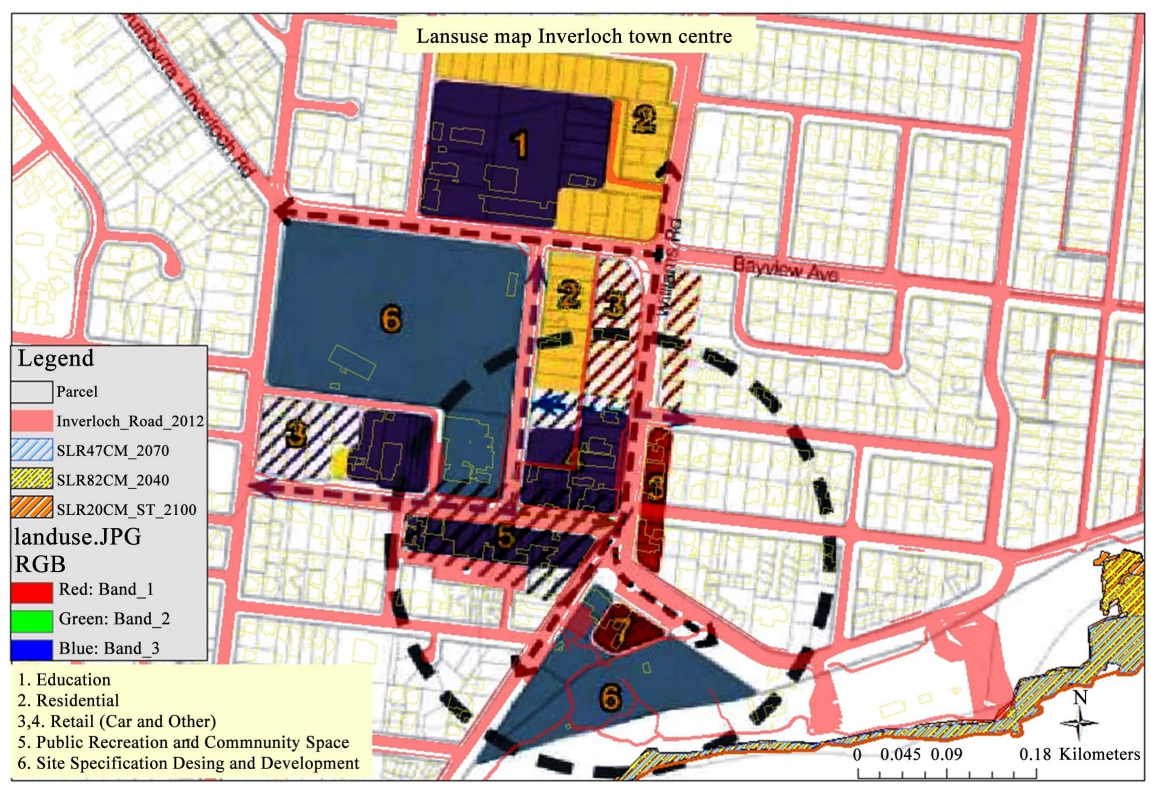

Figure 10. Commeand residential land use at risk of sea-level rise flooding 4.1.

reason for this is to identify the different types of land use that would be affected by each flood type and identify by number and percentage the proportion and area of each land use that falls within the flood zone. This works in a very similar fashion to that of the roads, by supplying the select location to find land use polygons that intersect with the flood areas. By using the geoprocessing clip tool to make the land use polygon clip from the flood polygons the land use affected by floods in Inverloch is shown. There are two main areas of concern, the foreshore in front of the Inverloch Surf Lifesaving Club (SLSC) and the foreshore in front of Bunurong Road where erosion threatens to affect public assets.

\section{GIS-Based Scenario Modelling}

This research also discusses total road area in Inverloch is 63.70 Hectares (ha). By 2100 SLR Identifying Road Infrastructure at Risk will be 1.35 Hectares (ha) and $0.86 \%$ of roads will be flooded. In 2040, $0.95 \mathrm{sq} \cdot \mathrm{km}, 8.75 \%$. In 2070, 1.09 sq.km, $10.03 \%$ and in $21001.16 \mathrm{sq} \cdot \mathrm{km}, 10.67 \%$.

In Figure 11 the roads are shown as a dark olive-green shade, with the most 


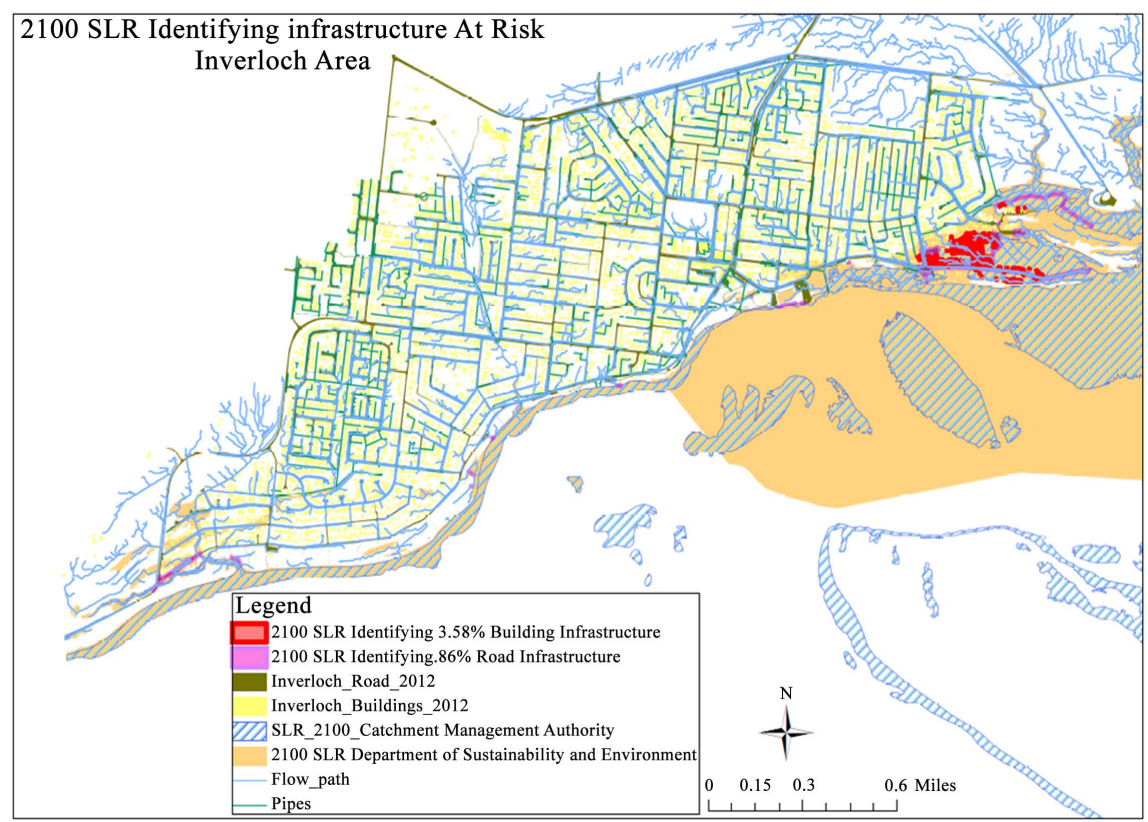

Figure 11. Inverloch climate-adapted settlement in 2100 SLR identifying assets at risk.

exposed roads shown as dark pink. The buildings are shaded yellow, with the most exposed shaded as dark red. When overlayed on the buildings' footprints buildings were identified as being highly vulnerable as those in the highest level (red colour here) and the lowest vulnerability in yellow and it is evident that most buildings are exposed. The most highly exposed roads (143 kilometres) and buildings (6100) were in the Inverloch holiday park area, with 65 buildings were exposed in the Screw Creek area. These are most evident at the eastern end of the image.

\section{Conclusions}

The model results clearly show that the town of Inverloch will experience a shift due to climate change, and most likely for the worse. A constructive action or an early intervention would certainly cost less in the end than leaving it too late for the future. Research tools provide a practical approach to address current and future climate risk on coastal infrastructure assets and operations. While a broad range of potential resilience and adaptation measures have been identified, it should be noted that climate risk management is a "long game" issue and there is no single approach or tool that can effectively eliminate climate risk in the short term.

\section{Conflicts of Interest}

The authors declare no conflicts of interest regarding the publication of this paper.

\section{References}

[1] Church, J.A., Clark, P.U., Cazenave, A., Gregory, J.M., Jevrejeva, S., Levermann, A., 
Merrifield, M.A., Milne, G.A., Nerem, R.S., Nunn, P.D., Payne, A.J., Pfeffer, W.T., Stammer, D. and Unnikrishnan, A.S. (2013) Sea level Change. In: Stocker, T., Qin, F.D., Plattner, G.-K., et al., Eds., Climate Change 2013: The Physical Science Basis. Contribution of Working Group I to the Fifth Assessment Report of the Intergovernmental Panel on Climate Change, Cambridge University Press, Cambridge, $1137-1216$.

[2] Lough, J.M. and Hobday, A.J. (2011) Observed Climate Change in Australian Marine and Freshwater Environments. Marine and Freshwater Research, 62, 984-999. https://doi.org/10.1071/MF10272

[3] Keenan, T.D. and Cleugh, H.A. (2011) Climate Science Update: A Report to the 2011 Garnaut Review, Citeseer. The Centre for Australian Weather and Climate Research, CAWCR Technical Report No. 036.

http://www.bom.gov.au/research/publications/cawcrreports/CTR_036.pdf

[4] Schaeffer, M., Hare, W., Rahmstore, S. and Vermeer, M.J.N.C.C. (2012) Long-Term Sea-Level Rise Implied by $1.5^{\circ} \mathrm{C}$ and $2^{\circ} \mathrm{C}$ Warming Levels. Nature Climate Change, 2, 867-870. https://doi.org/10.1038/nclimate1584

[5] Natesan, U. and Parthasarathy, A.J.J.O.C.C. (2010) The Potential Impacts of Sea Level Rise along the Coastal Zone of Kanyakumari District in Tamilnadu, India. Journal of Coastal Conservation, 14, 207-214. https://doi.org/10.1007/s11852-010-0103-6

[6] Kuleli, T., Şenkal, O. and Erdem, M. (2009) National Assessment of Sea Level Rise Using Topographic and Census Data for Turkish Coastal Zone. Environmental Monitoring and Assessment, 156, Article No. 425. https://doi.org/10.1007/s10661-008-0495-Z

[7] El-Nahry, A.H. and Doluschitz, R. (2010) Climate Change and Its Impacts on the Coastal Zone of the Nile Delta, Egypt. Environmental Earth Sciences, 59, 1497-1506 https://doi.org/10.1007/s12665-009-0135-0

[8] Gravelle, G. and Mimura, N. (2008) Vulnerability Assessment of Sea-Level Rise in Viti Levu, Fiji Islands. Sustainability Science, 3, 171-180. https://doi.org/10.1007/s11625-008-0052-2

[9] Osbaldiston, N., Picken, F. and Duffy, M. (2015) Characteristics and Future Intentions of Second Homeowners: A Case Study from Eastern Victoria, Australia. Journal of Policy Research in Tourism, Leisure and Events, 7, 62-76. https://doi.org/10.1080/19407963.2014.934689

[10] Pais-Barbosa, J., Veloso-Gomes, F. Andtaveira-Pinto, F. (2010) Gis tool for Coastal Morphodynamics Analysis. Coastal and Marine Geospatial Technologies, 13, 275-283. https://doi.org/10.1007/978-1-4020-9720-1_26

[11] Hennecke, W.G., Greve, C.A., Cowell, P.J. and Thom, B.G. (2004) Gis-Based Coastal Behavior Modeling and Simulation of Potential Land and Property Loss: Implications of Sea-Level Rise at Collaroy/Narrabeen Beach, Sydney (Australia). Coastal Management, 32, 449-470. https://doi.org/10.1080/08920750490487485

[12] Ivajnšič, D. and Kaligarič, M. (2014) How to Preserve Coastal Wetlands, Threatened by Climate Change-Driven Rises in Sea Level. Environmental Management, 54, 671-684. https://doi.org/10.1007/s00267-014-0244-8

[13] Poppenga, S.K., Worstell, B.B., Stoker, J.M. and Greenlee, S.K. (2010) Using Selective Drainage Methods to Extract Continuous Surface Flow from 1-Meter Lidar-Derived Digital Elevation Data. US Geological Survey. https://doi.org/10.3133/ofr20105059

[14] Balstrom, T. and Crawford, D. (2018) Arc-Malstrøm: A 1D Hydrologic Screening 
Method for Stormwater Assessments Based on Geometric Networks. Computers \& Geosciences, 116, 64-73. https://doi.org/10.1016/j.cageo.2018.04.010

https://www.researchgate.net/publication/324711242_Arc-Malstrom_A_1D_hydrol og-

ic_screening_method_for_stormwater_assessments_based_on_geometric_networks 